\title{
GE 13: The Influence of Ethnic Newspapers in Shaping the Opinion of Indian and Chinese Voters
}

\author{
ZETI AZREEN AHMAD \\ ISMAIL S.Y. AHMED \\ HARTINI WAKICHAN \\ HAZWANI HALEM \\ International Islamic University Malaysia \\ azreen@iium.edu.my \\ daaha93@hotmail.com \\ hartiniwakichan@gmail.com \\ hazwani.halem@gmail.com \\ SITI HASLINA HUSSIN \\ Universiti Malaysia Sarawak \\ hhaslina@unimas.my \\ MUTIU ADEKUNLE GANIYU \\ Universiti Utara Malaysia \\ justmutiu2009@gmail.com
}

\begin{abstract}
This paper attempts to assess the role of Tamil and Chinese newspapers in exerting influence on Indian and Chinese voters, before and after Malaysia's 2013 General Election (GE13). This study employs both content analysis and survey to examine media agenda and public agenda specifically the Chinese and Indian ethnic groups. In total, 4,951 news items were obtained from two major language newspapers comprising Sin Chew, Nanyang Siang Pau, Tamil Nesan and Malaysia Nanban, during the election campaign period. These news items have been coded according to seventeen categories. A total of 754 Chinese and 183 Indians had participated in the public opinion survey conducted before the general election, and a total of 618 Chinese and 122 Indians responded after the general election. This study found that both Tamil and Chinese newspapers did not influence the agenda of the Chinese and Indian respondents nationwide. Politics appeared as the top issue reported in both ethnic newspapers while crime appeared as the most important issue of concern to both Chinese and Indian respondents.
\end{abstract}

Keywords: Chinese newspapers, Tamil newspapers, GE13, media agenda, public agenda

\section{INTRODUCTION}

This paper attempts to assess the role of Chinese and Tamil newspapers in exerting influence on Chinese and Indian's public agenda, before and after Malaysia's 2013 General Election. The study has adopted an agenda setting approach in which content analysis and survey were employed to examine media agenda of the selected newspapers and public agenda of the two ethnic groups. Agenda setting is not a new theory. The waves of agenda-setting 